\title{
A feltárás módjának hatása a közvetlen posztoperatív időszakra teljes felszínpótló térdprotézis beültetése esetén
}

\author{
Bejek Zoltán dr. - Holnapy Gergely dr. - Skaliczki Gábor dr. \\ Stubnya Bence oh. - Szatmári Attila dr.
}

Semmelweis Egyetem, Általános Orvostudományi Kar, Ortopédiai Klinika, Budapest

Bevezetés: A teljes felszínpótló térdprotézis beültetése az ortopédsebészet egyik legsikeresebb és legbiztonságosabb beavatkozásává vált. A számos eltérô feltárásmód közül a leginkább elterjedt, úgynevezett medialis parapatellaris (MP-) feltárás során a musculus quadriceps ina átvágásra kerül, károsítva az extensor funkciókat. Ezzel szemben a subvastus (S-) feltárás - megkímélve az extensor apparátust - kevesebb fájdalommal járó, gyorsabb rehabilitációt ígérhet.

Célkitüzés: A Semmelweis Egyetem Ortopédiai Klinikáján végzett prospektív, obszervációs vizsgálatunk célja az MPés az S-feltárás közvetlen posztoperatív időszakra való hatásának összehasonlítása.

Módszer: A bevont 60 beteg a beavatkozás típusa szerint random módon két eltérô csoportba került. A vizsgálat során homogén betegcsoportokon mértük a két eltérő feltárásmód hatásait a korai posztoperatív időszakban a nemzetközi szakirodalom és az általunk meghatározott paraméterek alapján.

Eredmények: Vizuális analóg skála (VAS) segítségével nyugalmi és aktív fájdalomszintet mértünk az első 10 napon, ami alapján az aktív VAS-értékek esetén szembetünőbb a különbség az S-csoport javára. Az aktív VAS esetében az S-csoportban a 2., 3., 10. napon is szignifikánsan kisebb fájdalmat jeleztek a betegek, mint az MP-csoportban. A többi nap eredményeit is figyelembe véve, ez amellett szól, hogy az extensor apparátus integritásának megőrzése jobb posztoperatív funkcionalitást tesz lehetővé. Megmértük a betegek térdízületi mozgástartományát is. Az l. napon az S-csoportba tartozóké szignifikánsan nagyobb. A napok előrehaladtával az MP-csoport tagjai a rehabilitációjuk során utolérik az S-csoportot. Az S-csoportba tartozók átlagosan 1,944 nappal, azaz közel két nappal korábban képesek nyújtva lábat emelni, szemben az MP-csoporttal $(\mathrm{p}<0,0001)$.

Következtetések: Az adatok statisztikai elemzése után elmondható, hogy a subvastus feltárás előnyösebbnek látszik a közvetlen posztoperatív időszak rehabilitációja tekintetében. Evidencia felállításához azonban további nagy elemszámú, multicentrikus, obszervációs vizsgálatokra van szükség.

Orv Hetil. 2020; 161(29): 1208-1214.

Kulcsszavak: térdsebészet, teljes felszínpótló endoprotetika, subvastus, medialis parapatellaris

\section{Effect of the surgical exposure on the early postoperative period after total knee arthroplasty}

Introduction: Total knee arthroplasty has become one of the most successful and safest surgical procedures in orthopedic surgery. Of the many different types of surgical exposure, the most common, so-called medial parapatellar (MP) incision is the cut of the quadriceps tendon, which impairs extensor function. In contrast, subvastus (S) exposure, which spares the extensor apparatus, may promise better healing.

Aim: The purpose of our prospective observational study at the Orthopedic Clinic of Semmelweis University is to compare the effects of the MP and the $S$ excision on the early postoperative period.

Method: The 60 patients enrolled were randomly assigned to two different groups according to the type of intervention. In the study, we measured the effects of the two different methods of surgical exposure on homogeneous patient groups in the early postoperative period based on international literature and the parameters we defined.

Results: Visual analog scale (VAS) measured resting and active pain levels for the first 10 days, suggesting a more pronounced difference in active VAS values for the $S$ group. In the case of active VAS, patients in the $S$ group also 
had significantly less pain on days 2, 3, and 10 than in the MP group. Taking into account the results of the other days, it is in favour of preserving the integrity of the extensor apparatus for improved postoperative functionality. Patients' knee joint range of motion was also measured. On day 1 , those in the $S$ group were significantly larger. As the days progress, MP group members catch up with $S$ group during their rehabilitation. Group $S$ patients had an average of 1.944 days to extended leg elevation, which is nearly two days shorter compared to the MP group $(\mathrm{p}<0.0001)$.

Conclusions: After statistical analysis of data, subvastus exposure appears to be more beneficial in the rehabilitation of the early postoperative period. However, large-scale, multicentre observational studies are required to establish evidence.

Keywords: knee surgery, total knee arthroplasty, subvastus, medial parapatellar

Bejek Z, Holnapy G, Skaliczki G, Stubnya B, Szatmári A. [Effect of the surgical exposure on the early postoperative period after total knee arthroplasty]. Orv Hetil. 2020; 161(29): 1208-1214.

(Beérkezett: 2020. március 3.; elfogadva: 2020. április 7.)

\section{Rövidítések}

ANOVA $=($ analysis of variance $)$ varianciaanalízis; $\mathrm{CI}=($ confidence interval) konfidenciaintervallum; $\mathrm{MP}=$ medialis parapatellaris; $\mathrm{ROM}=$ (range of motion) mozgástartomány; $\mathrm{S}=$ subvastus; $\mathrm{SD}$ = standard deviáció; VAS = vizuális analóg skála

A nagyízületi endoprotetika, különösen a térd- és a csípőízület esetében, az ortopéd sebészet legsikeresebb beavatkozásává vált az elmúlt évtizedekben, kimagaslóan jó eredményeket biztosítva egyre szélesebb rétegek számára. Ahogy a beavatkozások biztonságossága egyre növekedett, úgy növekedett folyamatosan és növekszik ma is a mütétek száma: 2005-ben Kurtz és mtsai 2030-ra csípőprotézis esetében 170\%-os, térdprotézis esetében 600\%-os emelkedést jósoltak [1]. A teljes felszínpótló térdprotézis-beültetések számának emelkedésén kivül a sebészeti technika is komoly fejlődésen ment keresztül, elótérbe került a minél teljesebb és gyorsabb rehabilitáció, valamint ezzel együtt a mútéttel járó ápolási napok lerövidítésének igénye is. Ez az igény hívta életre az angolszász területeken mára igen széles körben elterjedt és sikerrel alkalmazott „gyorsított gyógyulás” (enhanced recovery) metódust, amellyel a betegeket már a mútét napján lábra állítják, megkezdik rehabilitációjukat, és a mútét után 2-3 nappal otthonukba bocsátják óket úgy, hogy teljesen önellátóak [2].

Az ortopéd sebészetben mára számos különböző feltárásmódot dolgoztak ki és követnek világszerte. Közülük kettő azonban gyakoriságában megelőzi az összes többit. A medialis parapatellaris feltárás során a musculus quadriceps ina átmetszésre kerül, ami - károsítva az extensor apparátust - hosszabb és nehezebb posztoperatív rehabilitációs időszakot okozhat. Berstock és mtsai 2018 ban végeztek egy átfogó metaanalízist a témában: felmérésük szerint az Egyesült Királyságban az ortopéd sebészek 93\%-a választja a medialis parapatellaris eljárást, és csupán 1\%-uk végez teljes felszínpótló térdprotézis-beültetést subvastus feltárással. Ez utóbbit először 1929-ben írta le Erkes [3], de igazán Hofmann és mtsai 1991-es publikációja után tett szert széles körú ismertségre és elfogadásra [4]; előnye, hogy megőrzi a quadriceps izom épségét, ami jobb posztoperatív izomerôt és funkciót eredményezhet [5], megőrzi a patella vérellátását [6], jobb a posztoperatív patellaris mechanika [7], és kisebb posztoperatív fájdalommal jár. Mindezek eredményeképpen meggyorsítja a rehabilitációt, és lerövidíti a szükséges kórházi tartózkodás idejét [8-10].

Számos tanulmány foglalkozik a medialis parapatellaris és a subvastus feltárás utáni közvetlen posztoperatív rehabilitáció sikerességével, a korábbi évek során publikált tanulmányok jelentős része azonban a medialis parapatellaris eljárást hasonlítja az összes többi feltárásmódhoz, nem specifikálva egy adott alternatív feltárásmódra - így a szakirodalomban jelentősen kevesebb tanulmány foglalkozik kifejezetten a medialis parapatellaris és a subvastus feltárás összehasonlításával. Ez magyarázza, hogy Berstock és mtsai a 2018-ban megjelent metaanalízisükbe csak 20 tanulmányt tudtak bevonni, amely szám az alcsoportelemzéseik során tovább redukálódott [8]. A témával foglalkozó korlátozott szakirodalom nem mindig szignifikáns eredményeinek tudható be, hogy ma még nincs egyértelmú, magas szintű evidencia, amely az egyik feltárás javára döntene. A rendelkezésre álló randomizált kontrollvizsgálatok kis elemszámúak, és nem szemléltetik megfelelően a klinikailag releváns különbségeket [8].

Tanulmányunkban a Semmelweis Egyetem Ortopédiai Klinikáján kizárólag a medialis parapatellaris és a subvastus feltárásnak a közvetlen posztoperatív időszakra való hatását mérô prospektív, obszervációs vizsgálat eredményeit dolgoztuk fel.

Az irodalmi adatok és a Semmelweis Egyetem Ortopédiai Klinikáján tapasztaltak alapján célunk az volt, hogy kizárólag a medialis parapatellaris és a subvastus feltárásnak a közvetlen posztoperatív időszakra, rehabilitációra kifejtett hatását hasonlítsuk össze primer teljes felszínpótló térdprotézis beültetése során egy prospektív, obszervációs vizsgálat keretében. 
1. táblázat |A beválasztott betegek adatai

\begin{tabular}{l|cc|cc|c}
\hline & \multicolumn{2}{|c|}{ Medialis parapatellaris } & \multicolumn{2}{c}{ Subvastus } & \multirow{2}{*}{ p-érték } \\
& Átlag & SD & Átlag & SD & \\
\cline { 2 - 5 } Kor $($ év) & 67,1 & 8,983 & 70,85 & 8,675 & 0,1122 \\
\hline Testsúly $(\mathrm{kg})$ & 92,07 & 16,64 & 84,24 & 10,84 & 0,0473 \\
\hline BMI $\left(\mathrm{kg} / \mathrm{m}^{2}\right)$ & 33,36 & 4,62 & 30,74 & 4,207 & 0,1163 \\
\hline Mǘtéti idő $(\mathrm{min})$ & 87,53 & 19,4 & 84,94 & 18,17 & 0,5212 \\
\hline Esmarch-idó $(\mathrm{min})$ & 64 & 12,37 & 61,43 & 19,62 & 0,9609 \\
\hline Vérvesztés $(\mathrm{ml})$ & 256,7 & 103,2 & 274,2 & 205,4 & 0,2849 \\
\hline
\end{tabular}

$\mathrm{BMI}=$ testtömegindex $; \mathrm{CI}=$ konfidenciaintervallum; $\mathrm{SD}=$ standard deviáció

\section{Módszer}

Vizsgálatunkba összesen 60, az Ortopédiai Klinikán 2018. március és 2018. november között operált beteg került bevonásra. Medialis parapatellaris és subvastus feltárást is egyenlően 30-30 betegen végeztünk, akiket az operációt követő 10 napon szorosan követtünk, ezt követően pedig 6 hetes, illetve 1 éves kontrollvizsgálatot végeztünk (1. táblázat).

A homogén betegcsoportokon a feltárásnak a korai posztoperatív funkcióra gyakorolt hatásairól, a fájdalomról, a mütéti időről és a mütéti vérvesztésről történt vizsgálat. Meghatároztuk és összehasonlítottuk, hogy hányadik posztoperatív napon tudják nyújtva megemelni az operált lábukat a betegek, mikor állnak fel először, és mikor érik el a 90 fokos flexiót. A fájdalomszint mérése vizuális analóg skálával (VAS) történt nyugalmi és aktív állapotban. A jelen cikkben a VAS-értékeket, az ízületi mozgástartomány és a mobilizálhatóság alakulását közöljük.

Adataink összegyưjtését követően, azok elemzésére Mann-Whitney-féle U-próbát alkalmaztunk a GraphPad Prism 8 szoftver (GraphPad Software Inc., San Diego,
CA, Amerikai Egyesült Allamok) segítségével. Számításaink során $\mathrm{p}<0,05$ szignifikanciaszintet határoztunk meg; adathalmazunkban kiugró értéket nem tapasztaltunk. Az alcsoportokon belüli interakciós hatás meghatározására ANOVA-próbát futtattunk le.

\section{Eredmények}

\section{Posztoperatín fájdalom}

A posztoperatív fájdalom felmérésére a 0-tól 10-ig terjedő VAS-pontrendszert használtuk, amelyben minél nagyobb az érték, annál nagyobb a beteg fájdalma. A VASértékeket az első 10 napon aktív körülmények között, a nyugalmi VAS-értéket ezenkívül az operáció napján is megvizsgáltuk.

\section{Nyugalmi vizuális autológskála-értékek}

A nyugalmi VAS-értékek összehasonlítása után látszik, hogy a 0. napon érdemi különbség nincs az MP- és az Scsoport között. Az 1. (átlagkülönbség: 1,465, p = 0,0509)

2. táblázat |A nyugalmi VAS-értékek összefoglalása

\begin{tabular}{|c|c|c|c|c|c|c|c|}
\hline \multirow[t]{2}{*}{ Napok } & \multicolumn{2}{|c|}{ Medialis parapatellaris } & \multicolumn{2}{|c|}{ Subvastus } & \multicolumn{2}{|c|}{ Átlagkülönbség } & \multirow[t]{2}{*}{ p-érték } \\
\hline & Átlag & SD & Átlag & SD & Átlag & $95 \% \mathrm{CI}$ & \\
\hline 0. & 4,323 & 2,587 & 3,939 & 2,164 & 0,384 & {$[-0,805 ; 1,573]$} & 0,6445 \\
\hline 1. & 5,677 & 3,004 & 4,212 & 2.369 & 1,465 & {$[0,118 ; 2,812]$} & 0,0509 \\
\hline 2. & 4,452 & 2,095 & 3,545 & 1,938 & 0,907 & {$[-0,101 ; 1,915]$} & 0,066 \\
\hline 3. & 4,065 & 2,016 & 2,97 & 1,845 & 1,095 & {$[0,130 ; 2,060]$} & 0,0084 \\
\hline 4. & 3,355 & 1,704 & 2,879 & 1,728 & 0,476 & {$[-0,382 ; 1,334]$} & 0,1875 \\
\hline 5. & 2,903 & 1,491 & 2,848 & 1,787 & 0,055 & {$[-0,770 ; 0,880]$} & 0,5204 \\
\hline 6. & 2,871 & 1,477 & 2,788 & 1,536 & 0,083 & {$[-0,671 ; 0,837]$} & 0,7375 \\
\hline 7. & 2,258 & 1,341 & 2,4 & 1,453 & $-0,142$ & {$[-0,858 ; 0,574]$} & 0,7942 \\
\hline 8. & 2,2 & 1,155 & 2,222 & 1,368 & $-0,022$ & {$[-0,730 ; 0,686]$} & 0,7364 \\
\hline 9. & 1,818 & 0,795 & 2,043 & 1,581 & $-0,225$ & {$[-0,983 ; 0,533]$} & 0,5547 \\
\hline 10 & 1,533 & 0,743 & 1,632 & 1,012 & $-0,099$ & {$[-0,735 ; 0,537]$} & $>0,9999$ \\
\hline
\end{tabular}

$\mathrm{CI}=$ konfidenciaintervallum; SD = standard deviáció; VAS = vizuális analóg skála 


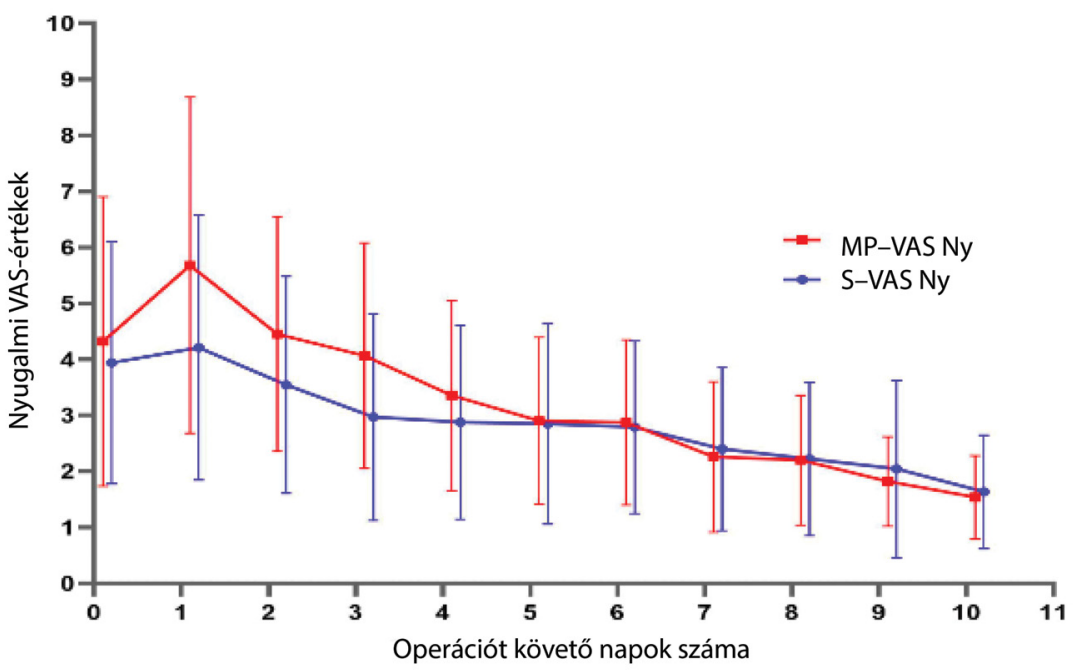

1. ábra $\mid \begin{aligned} & \text { A nyugalmi VAS-értékek ábrázolása } \\ & \mathrm{MP}=\text { medialis parapatellaris; } \mathrm{S}=\text { subvastus; VAS = vizuális analóg skála }\end{aligned}$

és a 2. (átlagkülönbség: 0,907,p = 0,066) napon azonban látszik, hogy a kíméletesebb feltárásnak köszönhetően az S-csoportban kisebb a betegek fájdalma, noha ez az eltérés nem szignifikáns. A 3. napon azonban már szignifikánsan kisebb, átlagosan 1,095 ponttal enyhébb fájdalomról számoltak be az S-csoportba tartozók, mint az MP-csoportba tartozók (átlagkülönbség: 1,095, p = 0,0084). A 4. naptól kezdve, egyre nagyobb p-értékek mellett eltúnik a kezdeti különbség a két csoport között. Szignifikáns (p $=0,0223$ ) interakciós hatás van a két csoport között a nyugalmi VAS-értékek tekintetében (2. táblázat, 1. ábra).

Berstock és mtsai metaanalízisükben csak az első nap eredményeit tudták összemérni: 512 térd bevonásával azt állapították meg, hogy az S-csoportba tartozók átlagosan 0,8 ponttal kisebb nyugalmi VAS-értéket adtak $(95 \%$ CI $0,2-1,35 ; \mathrm{p}=0,006)[8]$.

\section{Aktív vizuális autológskála-értékek}

Az aktív VAS-értékek között mind a 10 napon szembetûnőbb a két csoport közötti differencia az S-csoport javára. Aktív VAS-értéket mindkét csoportban az 1. posztoperatív naptól kezdve mértünk. Az adatok alapján kimondható, hogy a 2. (átlagkülönbség: 1,128, p = 0,0127 ), a 3. (átlagkülönbség: $1,402, \mathrm{p}=0,0026$ ) és a 10. (átlagkülönbség: $1,189, \mathrm{p}=0,0045$ ) napon is szignifikánsan kisebb fájdalmat jeleztek a betegek. Látszik továbbá a feltüntetett értékek alapján, hogy az 1. (átlagkülönbség: 1,158, p =0,0657), a 4. (átlagkülönbség: $1,009, \mathrm{p}=0,0529$ ) és a 9. (átlagkülönbség: 0,753, $\mathrm{p}=0,0522)$ napon is a szignifikanciahatárhoz közeli a különbség a fájdalom tekintetében (4. táblázat, 2. ábra).

3. táblázat |A ROM-értékek összefoglalása

\begin{tabular}{|c|c|c|c|c|c|c|c|}
\hline \multirow[t]{2}{*}{ Napok } & \multicolumn{2}{|c|}{ Medialis parapatellaris } & \multicolumn{2}{|c|}{ Subvastus } & \multicolumn{2}{|c|}{ Átlagkülönbség } & \multirow[t]{2}{*}{ p-érték } \\
\hline & Átlag & SD & Átlag & SD & Átlag & $95 \% \mathrm{CI}$ & \\
\hline 0. & 49,35 & 30,98 & 49,09 & 28,1 & 0,26 & {$[-15,024 ; 14,504]$} & 0,9115 \\
\hline 1. & 37,74 & 22,32 & 52,19 & 20,75 & $-14,45$ & {$[3,597 ; 25,303]$} & 0,003 \\
\hline 2. & 50 & 22,21 & 59,38 & 21,69 & $-9,38$ & {$[-1,680 ; 20,440]$} & 0,0880 \\
\hline 3. & 63,87 & 20,92 & 66,67 & 18,98 & $-2,8$ & {$[-7,171 ; 12,771]$} & 0,5728 \\
\hline 4. & 68,71 & 21,41 & 73,33 & 17,62 & $-4,62$ & {$[-5,153 ; 14,393]$} & 0,3872 \\
\hline 5. & 76,67 & 16,05 & 79,39 & 16,76 & $-2,72$ & {$[-5,566 ; 11,006]$} & 0,2933 \\
\hline 6. & 80,97 & 13,5 & 83,33 & 14,29 & $-2,36$ & {$[-4,596 ; 9,316]$} & 0,2188 \\
\hline 7. & 86,13 & 13,08 & 87,67 & 15,01 & $-1,54$ & {$[-5,666 ; 8,746]$} & 0,3214 \\
\hline 8. & 87,2 & 13,08 & 89,63 & 14,8 & $-2,43$ & {$[-5,375 ; 10,235]$} & 0,1831 \\
\hline 9. & 90,45 & 11,74 & 93,04 & 14,9 & $-2,59$ & {$[-5,499 ; 10,679]$} & 0,1821 \\
\hline 10. & 92 & 10,82 & 94,21 & 12,61 & $-2,21$ & {$[-6,134 ; 10,554]$} & 0,3601 \\
\hline
\end{tabular}

$\mathrm{CI}=$ konfidenciaintervallum; $\mathrm{ROM}$ = mozgástartomány; $\mathrm{SD}$ = standard deviáció 
4. táblázat |Az aktív VAS-értékek összefoglalása

\begin{tabular}{|c|c|c|c|c|c|c|c|}
\hline \multirow[t]{2}{*}{ Napok } & \multicolumn{2}{|c|}{ Medialis parapatellaris } & \multicolumn{2}{|c|}{ Subvastus } & \multicolumn{2}{|c|}{ Átlagkülönbség } & \multirow[t]{2}{*}{ p-érték } \\
\hline & Átlag & SD & Átlag & SD & Átlag & $95 \% \mathrm{CI}$ & \\
\hline 1. & 7,613 & 2,201 & 6,455 & 2,463 & 1,158 & {$[-0,012 ; 2,328]$} & 0,0657 \\
\hline 2. & 6,613 & 2,044 & 5,485 & 1,986 & 1,128 & {$[0,121 ; 2,135]$} & 0,0127 \\
\hline 3. & 6.129 & 1,875 & 4,727 & 1,925 & 1,402 & {$[0,452 ; 2,352]$} & 0,0026 \\
\hline 4. & 5,645 & 1,924 & 4,636 & 1,934 & 1,009 & {$[0,044 ; 1,974]$} & 0,0529 \\
\hline 5. & 4,71 & 1,829 & 4,273 & $\mathrm{I}, 875$ & 0,437 & {$[-0,489 ; 1,363]$} & 0,2452 \\
\hline 6. & 4,581 & 1,747 & 3,848 & 1,734 & 0,733 & {$[-0,137 ; 1,603]$} & 0,0848 \\
\hline 7. & 4 & 1,673 & 3,567 & 1,591 & 0,433 & {$[-0,404 ; 1,270]$} & 0,282 \\
\hline 8. & 3,56 & 1,557 & 2,852 & 1,35 & 0,708 & {$[-0,102 ; 1,518]$} & 0,0848 \\
\hline 9. & 3,318 & 1,427 & 2,565 & 1,502 & 0,753 & {$[-0,129 ; 1,635]$} & 0,0522 \\
\hline 10. & 3,4 & 1,121 & 2,211 & 1,228 & 1,189 & {$[0,0357 ; 2,021]$} & 0,0045 \\
\hline
\end{tabular}

$\mathrm{CI}=$ konfidenciaintervallum; SD = standard deviáció; VAS = vizuális analóg skála

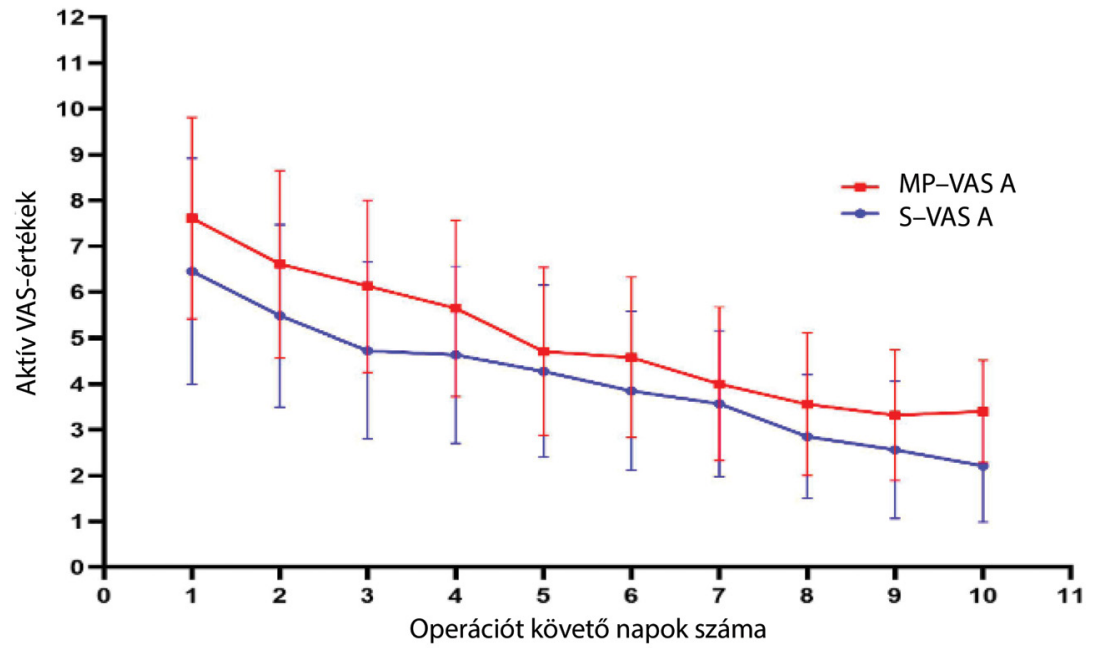

2. ábra

$\mid \begin{aligned} & \text { Az aktív VAS-értékek ábrázolása } \\ & \mathrm{MP}=\text { medialis parapatellaris; } \mathrm{S}=\text { subvastus; VAS = vizuális analóg skála }\end{aligned}$

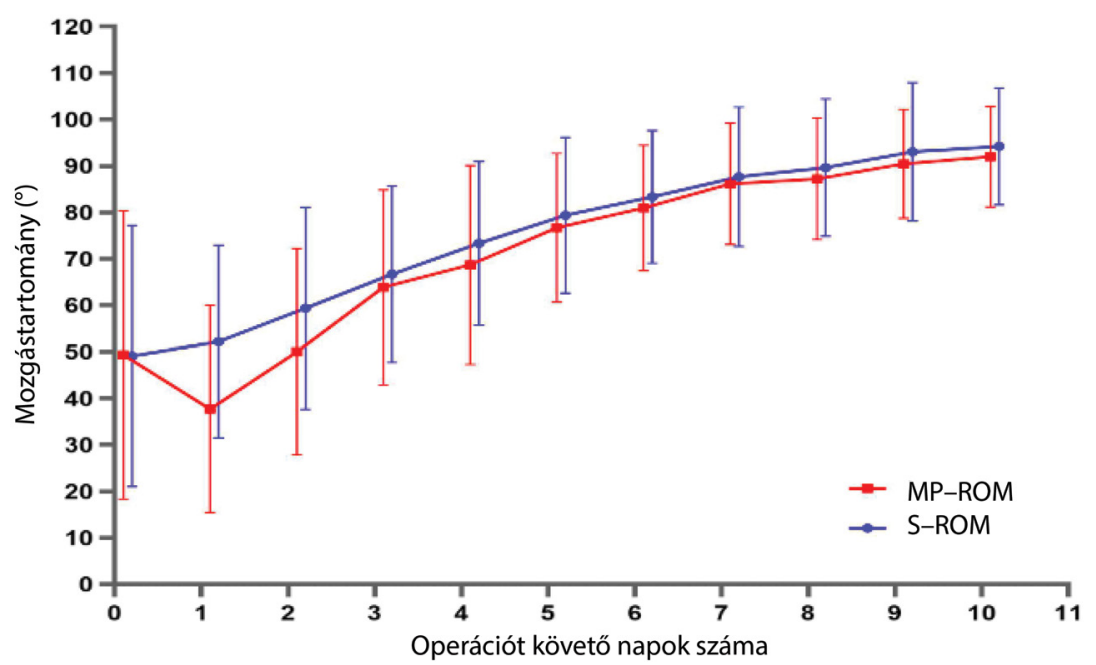

3. ábra

A ROM-értékek ábrázolása

$\mathrm{MP}=$ medialis parapatellaris $; \mathrm{ROM}=$ mozgástartomány; $S=$ subvastus 


\begin{tabular}{lllllllll|}
\hline & \multicolumn{2}{c|}{ Medialis parapatellaris } & \multicolumn{2}{c|}{ Subvastus } & \multicolumn{3}{c|}{ Átlagkülönbség } & \multirow{2}{*}{ p-érték } \\
\cline { 2 - 7 } & Átlag & SD & Átlag & SD & Átlag & $95 \%$ CI & \\
\hline Nyújtott lábemelés elsó napja & 3,065 & 2,128 & 1,121 & 0,4846 & 1,944 & {$[1,184 ; 2,704]$} & $<0,0001$ \\
\hline Talpra állás első napja & 1,194 & 0,5428 & 1,091 & 0,2919 & 0,103 & {$[-0,113 ; 0,319]$} & 0,5065 \\
\hline $90^{\circ}$-os mozgástartomány elérésének napja & 6,6 & 3,626 & 6 & 2,861 & 0,6 & {$[-1,038 ; 2,238]$} & 0,2993 \\
\hline
\end{tabular}

$\mathrm{CI}=$ konfidenciaintervallum; $\mathrm{SD}=$ standard deviáció

6. táblázat | Nemzetközi irodalmi kitekintés a nyugalmi VAS-értékek vonatkozásában Berstock és mtsai 2018-as metaanalízise alapján

\begin{tabular}{|c|c|c|c|c|c|c|c|}
\hline & \multicolumn{2}{|c|}{ Medialis parapatellaris } & \multicolumn{2}{|c|}{ Subvastus } & \multicolumn{2}{|c|}{ Átlagkülönbség } & \multirow[t]{2}{*}{ p-érték } \\
\hline & Átlag & SD & Átlag & SD & Átlag & $95 \% \mathrm{CI}$ & \\
\hline Saját eredmény & 5,677 & 3,004 & 4,212 & 2,369 & $-1,465$ & {$[-2,812 ;-0,118]$} & 0,0509 \\
\hline Jain 2013 & 4,6 & 4,6 & 3,8 & 4,6 & $-0,8$ & {$[-2,60 ;-1,00]$} & $<0,05$ \\
\hline Pan 2010 & 3,8 & 2,8 & 2,1 & 2,8 & $-1,7$ & {$[-3,03 ;-0,37]$} & 0,015 \\
\hline Bourke 2012 & 3,8 & 1,8 & 3,1 & 1,8 & $-0,7$ & {$[-1,51 ; 0,11]$} & $>0,05$ \\
\hline Tomek 2014 & 3,54 & 2,666 & 2,79 & 2,667 & $-0,85$ & {$[-1,64 ;-0,06]$} & 0,0358 \\
\hline van Hemert 2011 & 6,25 & 1,342 & 5 & 0,984 & $-1,25$ & {$[-1,96 ;-0,54]$} & $>0,05$ \\
\hline Koh 2016 & 3,75 & 0,9 & 3,7 & 0,9 & $-0,05$ & {$[-0,40 ; 0,30]$} & 0,768 \\
\hline
\end{tabular}

$\mathrm{CI}=$ konfidenciaintervallum; SD = standard deviáció

Az aktív VAS-értékekben tapasztalt különbség, bár összesen csak 3 napon szignifikáns, mégis azt a megfigyelést támasztja alá, miszerint az extensor apparátus integritásának megőrzése valóban jobb posztoperatív funkcionalitást tesz lehetővé [4].

\section{Funkcionalitás}

\section{Mozgástartomány}

Az operációt követően, a kórházi tartózkodás alatt minden nap megmérésre került a beteg operált lábának térdízületi mozgástartománya. Ahogy a 3. táblázat adatai is mutatják, az l. napon szignifikánsan nagyobb az S-csoportba tartozók mozgástartománya (átlagkülönbség: $\left.14,45^{\circ}, p=0,003\right)$, míg a 2 . napon ugyan nem szignifikáns, de jelentős előnye van az S-csoportnak (átlagkülönbség: $\left.9,38^{\circ}, \mathrm{p}=0,0880\right)$. A napok elörehaladtával az MP-csoport tagjai a rehabilitációjuk során utolérik az S-csoport mozgástartományát.

A szakirodalomban elérhető legfrissebb metaanalízis eredménye szerint a mozgástartományban a 7 . napon 7 fokos eltérés tapasztalható a subvastus csoport javára (95\% CI 3,21-10,73; p<0,0005) [8]. Ez szintén a kíméletesebb feltárás előnyét támasztja alá (5. táblázat, 3. ábra).

\section{A nyújtott lábemelés elsö napja}

Az S-csoportba tartozók átlagosan 1,944 nappal, azaz közel két nappal korábban képesek nyújtva lábat emelni, szemben az MP-csoportban levőkkel (átlagkülönbség: $1,944, \mathrm{p}<0,0001)$. Berstock és mtsai hasonló eredményre jutottak, szerintük a betegek átlagosan $1,68(\mathrm{p}<0,00001$, $\left.\mathrm{I}^{2}=89 \%\right)$ nappal korábban voltak képesek nyújtott láb megemelésére a subvastus csoportban, mint a medialis parapatellaris csoportban [8] (6. táblázat).

\section{A 90-os mozgástartomány elérésének napja}

A térdízületi mozgástartomány fejlódésében - ugyan nem szignifikánsan - szintén az S-csoportba tartozók teljesítettek jobban, átlagosan 0,6 nappal hamarabb érték el az említett intervallumot (átlagkülönbség: 0,6, $\mathrm{p}=0,2993)$ (5. táblázat).

\section{Megbeszélés}

Eredményeink alapján, amelyek jól illeszkednek a nemzetközi irodalomban ismert értékekhez (6. táblázat), a subvastus feltárás előnyösebbnek látszik a közvetlen posztoperatív időszak rehabilitációja tekintetében. A kisebb fájdalommal, kisebb fájdalomcsillapító-igénnyel, jobb funkciókkal járó subvastus eljárással a kórházi tartózkodás ideje is csökkenhet, ami mind a betegnek, mind az egészségügyi ellátórendszernek kedvező. A beteg hamarabb térhet vissza a nyugodt, otthoni körülményekhez, ahol nagyobb kényelemben folytathatja rehabilitációját, és hamarabb kerülhet vissza megszokott mindennapjaihoz. A korlátozott számú szignifikáns adat miatt azonban az eredmény nem kezelhető evidenciaként. Vizsgálatunkat tovább folytatjuk, mind a vizsgált popu- 
láció elemszámának növelésével, mind az utánkövetés idejéből származó adatok gyưjtésével és a megfelelő számú összegyuult adat esetén azok feldolgozásával.

Evidencia felállításához további nagy elemszámú, multicentrikus, obszervációs vizsgálatokra van szükség.

Anyagi támogatás: A jelen munka és eredményeinek megírása anyagi támogatásban nem részesült.

Szerzői munkamegosztás: B. Z., H. G., S. G., Sz. A.: A betegek kiválasztása, utánkövetés. B. Z., H. G., S. G.: A mútéti beavatkozás végrehajtása, az adatok összesítése. S. B.: Statisztikai elemzés. A szerzők a cikk végleges változatát elolvasták és jóváhagyták.

Érdekeltségek: A szerzőknek nincsenek érdekeltségeik.

\section{Irodalom}

[1] Kurtz S, Ong K, Lau E, et al. Projections of primary and revision hip and knee arthroplasty in the United States from 2005 to 2030. J Bone Joint Surg Am. 2007; 89: 780-785

[2] Stambough JB, Nunley RM, Curry MC, et al. Rapid recovery protocols for primary total hip arthroplasty can safely reduce length of stay without increasing readmissions. J Arthroplasty 2015; 30: 521-526.

[3] Erkes F. Further experience with physiological incision at the opening of the knee joint. [Weitere Erfahrungen mit physiolo- gischer Schnittführung zur Eröffnung des Kniegelenks.] Bruns' Beitr Klin Chir. 1929; 147: 221. [German]

[4] Hofmann AA, Plaster RL, Murdock LE. Subvastus (southern) approach for primary total knee arthroplasty. Clin Orthop Relat Res. 1991; 269: 70-77.

[5] Chang $\mathrm{CH}$, Chen $\mathrm{KH}$, Yang RS, et al. Muscle torques in total knee arthroplasty with subvastus and parapatellar approaches. Clin Orthop Relat Res. 2002; 398: 189-195.

[6] Kayler DE, Lyttle D. Surgical interruption of patellar blood supply by total knee arthroplasty. Clin Orthop Relat Res. 1988; 229: 221-227.

[7] Matsueda M, Gustilo RB. Subvastus and medial parapatellar approaches in total knee arthroplasty. Clin Orthop Relat Res. 2000; 371: 161-168.

[8] Berstock JR, Murray JR, Whitehouse MR, et al. Medial subvastus versus the medial parapatellar approach for total knee replacement: a systematic review and meta-analysis of randomized controlled trials. EFORT Open Rev. 2018; 3: 78-84.

[9] Lin TC, Wang HK, Chen JW, et al. Minimally invasive knee arthroplasty with the subvastus approach allows rapid rehabilitation: a prospective, biomechanical and observational study. J Phys Ther Sci. 2013; 25: 557-562.

[10] Unwin O, Hassaballa M, Murray J, et al. Minimally invasive surgery (MIS) for total knee replacement; medium term results with minimum five year follow-up. Knee 2017; 24: 454-459.

(Bejek Zoltán dr., Budapest, Üllői út 78/b, 1082 e-mail: bejzol@yahoo.com)

\section{"Ibi semper est victoria ubi concordia est." (Mindig ott van a győzelem, ahol az egyetértés.)}

A cikk a Creative Commons Attribution 4.0 International License (https://creativecommons.org/licenses/by/4.0/) feltételei szerint publikált Open Access közlemény, melynek szellemében a cikk bármilyen médiumban szabadon felhasználható, megosztható és újraközölhető, feltéve, hogy az eredeti szerző és a közlés helye, illetve a CC License linkje és az esetlegesen végrehajtott módositások feltüntetésre kerülnek. (SID_1) 